\title{
Analysis of Selection Criteria for Potential Subcontractors and Vendors and Their Role in Increasing Project Profits for Contractors
}

\author{
M. F. K. Darmawan ${ }^{1}$, A. D. Rarasati ${ }^{2}$, and A. Nursin ${ }^{3}$ \\ Civil Engineering Department, Faculty of Engineering, Universitas Indonesia, Kampus UI Depok, \\ Indonesia $16424^{1,2}$,Civil Engineering Department, Politeknik Negeri Jakarta, \\ Kampus Baru UI Depok, Indonesia $16425^{3}$ \\ muhammad.faozi4@gmail.com¹, ayomi@eng.ui.ac.id²,nursin_afrizal@yahoo.com.sg

\begin{abstract}
The policy of accelerating infrastructure development in Indonesia is one of the main focuses in realizing a sustainable development program. These efforts are inseparable from the role of the construction industry in realizing development in Indonesia. In carrying out the work, the main contractor will be supported by goods and service providers (subcontractors and vendors) as part of realizing construction project work. A business entity is established with the main objective being to obtain maximum profits including companies in the construction sector. The procurement activities of goods and services play an important and critical role. Thus, research needs to be done on the criteria for selecting suppliers of goods and services and their relationship with the role in leading project profits for contractors. The objective of this research will help the contractor to choose the best criteria for selecting subcontractors and vendors to increase profits.
\end{abstract}

Keywords: procurement, vendor, contractor, selection criteria, profit

\section{Introduction}

Indonesia is a developing country that makes accelerating infrastructure development one of the main focuses in realizing sustainable development programs. The realization of this program is in the Rencana Pembangunan Jangka Menengah Nasional (RPJMN) 2020-2024 where one of the seven agendas is to strengthen infrastructure to support economic development and basic services [1]. The construction industry plays an important role in Indonesia's development plans and with other industrial sectors in improving the Indonesian economy. In Indonesia, there is an increase in the number of construction companies each year, consisting of small, medium to large companies in the period 2014-2018 [2, 3, 4, 5, 6]. The increasing number of construction companies will further increase competition between companies in managing a national construction project.

The process of procuring goods and service providers is crucial because it will have an effect and can be a problem in completing construction projects, resulting in delays and increased costs. As many as $14 \%$ of the total construction projects occurred cost overruns and more than $70 \%$ of all construction projects occurred delays, and $10 \%$ of the project materials ended up being waste [7]. It is based that the cost of a project as a whole, $70 \%-80 \%$ is allocated for procurement activities in the form of goods and services, and in the procurement 
of goods (material) for project construction requires about $40 \%-50 \%$ of the total project cost $[8,9]$. Contractors generally tend to have a profit margin of $4 \%-12 \%$ of the project value, and generally in the range of $7 \%-9 \%$. but the percentage is reduced after the results of the project report which only reached $5 \%-6 \%$. This amount has not been reduced by head office overhead and other costs, so the total profit is only $2 \%$ - $4 \%$ [10]. Therefore, an analysis needs to be carried out on the selection criteria for the supply of goods and services in construction projects and the relationship between the selection activities of the selection of suppliers of goods and services to the objectives of the main contractor in achieving project profits.

\section{Method}

Literature review is used in this paper to find out more about the criteria for selecting suppliers of goods and services and their role in increasing project profits for contractors. appropriate literature is obtained by using keywords and certain combinations of words, namely "selection criteria" "subcontractors" "vendors" "roles of providers of goods and services" "contractors" "construction projects" "contractor profits" "project profits" "procurement ", and others related to this paper through a manual search on google. The results of the search on Google will obtain academic studies in the form of national and international journals, related books, and report data related to this paper. then journals and books are filtered according to topic relevance, which is the relationship between selection criteria and project profit for the contractor.

\section{Results and discussion}

Construction is an activity whose products are in the form of a building which is integrated with the position of the land which can be used as a residence or public infrastructure or other industries (roads, bridges, rail and railroad bridges, tunnels, water and drainage buildings, sanitation buildings, airstrips, docks, power plant buildings, transmission, distribution, and communication network buildings) [2]. According to data for the period 2014-2018, there has been an increase in the number of construction companies in Indonesia, consisting of small, medium to large companies $[2,3,4,5,6]$ that can be seen in table 1 .

Table 1. Qualification for the construction services business.

\begin{tabular}{ccc}
\hline Year & Number of construction companies & Growth rate (\%) \\
\hline 2014 & 128.819 & - \\
2015 & 134.029 & $3,24 \%$ \\
2016 & 142.852 & $6,58 \%$ \\
2017 & 155.833 & $9,09 \%$ \\
2018 & 160.576 & $3,04 \%$ \\
\hline
\end{tabular}

The data shows an increase in the number of construction companies in Indonesia each year. Construction companies in 2014 totaled 128,819, increasing to 134,029 in 2015 (3.24\%). in 2016 construction companies increased to 142,852 (6.58\%). In 2017 the highest increase was with the number of construction companies to $155,833(9.09 \%)$, and in 2018 there was an increase to $160,576(3.04 \%)[2,3,4,5,6]$. 
The contractor is a company and an individual who conducts business in the industrial sector which is commonly known as a construction contractor who contracts with clients [11]. The simplest understanding is that a contractor is a business entity that is leased or contracted by the project owner to carry out construction project work in accordance with the contract conditions that he has won [12]. The contractor is generally tasked with and responsible for managing projects such as contract administration with the owner (client), project financing, procurement of materials, equipment and services, as well as overseeing and controlling the progress of the project [13].

Subcontractors are construction companies that have agreed to a contract with the main contractor in carrying out certain work and activities on the project. Subcontractors are providers of goods and services that can supply workers, materials, tools, equipment, and project designs [14]. Subcontractors are more simply divided into two types, namely subcontractors that provide goods and services, or goods / services only [15]. The current selection system for goods and service providers in most companies, is based on a framework that starts with evaluating subcontractors based on certain criteria so that potential subcontractors will be obtained [16, $17,18]$. As a company, the main purpose of contractor company in conducting business activities is to maximize profits. therefore, the contractor will maximize profits and minimize costs in working on the project. This makes price one of the most important criteria for selecting suppliers of goods and services. generally, subcontractors that offer the lowest prices will most likely be chosen [19]. However, the selection criteria not only consider prices, but also consider other criteria, some of which are price, quality, service, delivery, certification, opportunities, benefits and risks are the main selection factors [20]. Quality, reputation, price and delivery are factors that must be considered in the selection process [21]. The most profitable bidder is determined by quality, price, technical assistance, timely delivery and more [22]. So, Price and quality are the main factors of the selection process [23].

Table 2. Selection criteria for goods and service providers and research indicators

\begin{tabular}{ll}
\hline \multicolumn{1}{c}{ Indicators } & Literature Sources \\
\hline Cost & {$[15,19,24,25,26,27]$} \\
Quality & {$[15,19,24,25,26,27,28]$} \\
Time & {$[15,19,26,27]$} \\
Organizational profile & {$[15,24,25,27]$} \\
Experience of the company & {$[15,19,25,26,27,28]$} \\
Technical capability & {$[15,24,25,26,28]$} \\
Management capability & {$[26,27,28]$} \\
Relationship with main contractor & {$[15,27]$} \\
Health and safety & {$[15,19,26,27,28]$} \\
Service levels & {$[19,25]$} \\
Disputes and risks & {$[19,26,27]$} \\
Geographical location & {$[24,25,27]$} \\
\hline
\end{tabular}

In table 2, we get several criteria for the selection of providers of goods and services from various literatures. Cost is a very important criterion for choosing potential providers of goods and services. the maximum profit will be achieved by minimizing costs [24]. In a study by Eriksson and Westerberg [29], the definition of quality is divided into two concepts, namely the quality of the final product and the quality of service during project work. one of several indicators of the success of a project work is if the process is in accordance with the predicted 
time (on schedule) [29]. The performance and history of past suppliers of goods and services helps in making decisions for their selection. Some components of organizational profile include; financial status, performance history, company size, organizational structure, and number of technical staff $[15,24,25,27]$. subcontractors experienced in implementing projects from the same field have less risk because subcontractors tend to have greater confidence in completing projects. it will also reduce costs because of the minimum risk that might occur [27]. Occupational health and safety criteria are needed in the selection of providers of goods and services that aim to determine the extent to which the company anticipates work accidents that may arise in the project work [28]. Service level indicators according to de felice et al [25], including repair services, reverse logistics, availability and ease of contact, communication systems, processing EDI (electronic data interchange), training aids, response to changes; quick response. The number and causes of disputes are taken into consideration in the selection by tracking historical subcontractor data on failure to complete and terminate the project $[19,26,27]$. In terms of geographical location, the project must not be too far away to make the shipping process easier. In addition, the location of the vendor and the possibility of natural disasters in the area must be checked before selecting a supplier of goods and services [24,27].

The subcontractor has an important role for the contractor, firstly, providing specialist staff in several project works. Construction projects have high complexity, so that the main contractor generally can not complete projects that have complexity and require the services of specialist personnel. Second, subcontractors are able to provide special tools, equipment, and special tool operators. The main contractor is not possible to own, operate, control, maintain the plant and special equipment which may be limited in number and operator power to all other projects being carried out. Third, subcontractors generally have experts so that they can perform specific tasks requiring expertise more quickly and with relatively lower costs and higher quality when compared to main contractors because of their skills [30, 31, 32]. The subcontracting system between the main contractor and the subcontractor will alleviate the problem of cash flow and project financing by subcontracting most of the work. In addition, the main contractor will also share project risks with subcontractors, so that it is possible for the main contractor to survive if the conditions of the construction industry become uncertain $[32,33]$. The following is a table of roles of providers of goods and services (table.3).

Table 3. The role of providers of goods and services and research indicators

\begin{tabular}{lc}
\hline \multicolumn{1}{c}{ Indicators } & Literature Sources \\
Labor & {$[10]$} \\
Material & {$[10]$} \\
Equipment & {$[10]$} \\
Method of Implementation & {$[10]$} \\
Finance & {$[10]$} \\
Health and safety & {$[10]$} \\
\hline
\end{tabular}

In table 3, we get several role of providers of goods and services from various literatures. Labor is an important thing in a project because it affects the cost and time of completion of a project work [10]. The competence, experience, and cooperative nature possessed by the laborer will influence the time management and quality of the project work $[19,26]$. In construction projects, procurement of goods for project development requires around $40 \%-50 \%$ of the total project cost [9]. Then, it needs good and proper management to buy, store, distribute, and 
count building materials so that the flow of materials on the project can run well. Material placed neatly will also support work effectiveness and work safety. During the implementation of the work on the project, every piece of equipment, especially heavy equipment must be carried out regularly, so that the condition of the equipment is always good and ready to use. this prevents damage to equipment that can interfere with project work [10]. in a study by Uluybeli et al. [27], Financial soundness is the basic element of responsibility and risk-sharing behaviour which is one of the most important advantages of subcontracting. If the subcontractor has a strong financial status, he can offer flexibility in the terms and conditions of progress payments [15]. The subcontractor's health and safety performance can affect the project and cause additional costs. Therefore, safety precautions and policies must be taken and understood by subcontractors [27].

There are four factors that indicate the success of a construction project, the project is running according to the contract schedule, earning benefits because of expenses as planned, minor problems occur in the project, and no work accidents occur [10]. In determining the feasibility and profitability of a project, effective management is needed in terms of financial inflows and outflows (cash flow) within a construction company for the duration of the project's working life [34]. Cash flow management is important for the contractor to be able to identify if there are cost overruns that might be caused by the delay in project time and maximization of profits or minimization of total project costs $[35,36]$. Company profitability can be analyzed by calculating the gross profit ratio, operating profit ratio, and return on capital employed ratio. Gross profit ratio is calculated to find the profitability of a business. The following is a table of and profitability indicator ratios (table.4).

Table 4. Project Profits and research indicators

\begin{tabular}{cc}
\hline Indicators & Literature Sources \\
\hline Gross Profit Ratio & {$[37]$} \\
Operational Profit Ratio & {$[37]$} \\
Return on capital employed ratio & {$[37]$} \\
\hline
\end{tabular}

If the gross profit ratio is high, this shows that the management is good. Operating profit ratio is calculated to determine the operational efficiency of management. if the operating profit ratio is high, it shows good business operational efficiency. The return on employed capital ratio is used to determine the relationship between earnings and capital employed and is calculated as a percentage by dividing net income by the capital employed [37].

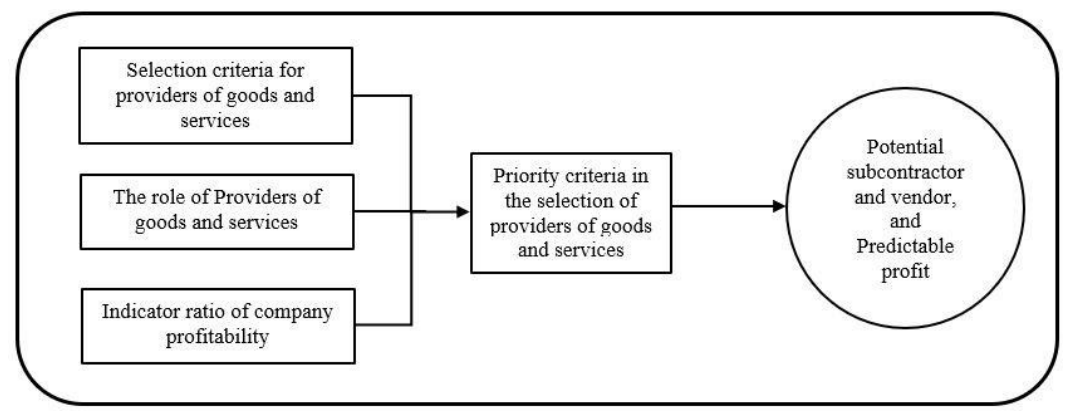

Fig.1. Conceptual framework about the flow of getting potential subcontractors and predicted profits. 
In figure 1. is the conceptual framework in this paper about getting potential subcontractors and predicted profits. The selection of the right suppliers of goods and services is important that must consider all aspects and consequences as a whole for the construction project and for the organization itself [18]. subcontractors can increase the possibility of higher profitability for both (main contractor and subcontractor), because subcontractors are able to provide fast assistance when needed so as to reduce the level of potential damage and recovery costs paid by the main contractor. In addition, specialized knowledge and efficient communication between the main contractor and subcontractors will improve work efficiency. it has an impact on increasing profitability by saving costs and time due to higher work efficiency [tan]. The conceptual framework in figure 1., seeks to relate the relationship between the selection criteria of goods and service providers and their role with project profits, so that priority criteria are obtained for the selection process. then, using these priority criteria, the main contractor will be able to select potential providers of goods and services (subcontractor and vendor) that will have an impact on the expected profil.

\section{Conclusion}

This paper develops how the selection of providers of goods and services is carried out by the main contractor. This paper provides the idea that in the selection process not only looks at the lowest price, but other criteria also affect project profits. in addition, the selection of providers of goods and services must also pay attention to their roles and functions in project work, so that the priority criteria in the selection process will be clearer and directly proportional to the influence of the providers of goods and services in the project. Priority criteria in the selection that are in line with the role of providers of goods and services and associated with profitability ratio indicators will make the initial profit expected by the contractor likely to be appropriate because it can be predicted. This will also have an impact on project time and quality, because project planning and work processes are more predictable.

This paper recommends that for subsequent research, it is necessary to consider nontechnical aspects that might be distracting or make predictions about initial earnings expectations being less precise. Especially in developing countries like Indonesia with a wide and varied geographical location, and an uncertain climate. These non-technical aspects include the state of the country's economy, government policies related to the construction industry, unpredictable seasons in Indonesia, and opportunities for illegal payments.

\section{References}

[1] Kementerian PPN / Bappenas: Rancangan Teknokratik Rencana Pembangunan Jangka Menengah Nasional 2020-2024. Indonesia Berpenghasilan Menengah - Tinggi yang Sejahtera, Adil, dan Berkesinambungan. pp. 1-315 (2019)

[2] Badan Pusat Statistik (BPS): Konstruksi Dalam Angka 2015. BPS, Jakarta. pp 1-93 (2015) 
[3] Badan Pusat Statistik (BPS): Konstruksi Dalam Angka 2016. BPS, Jakarta. pp 1-107 (2016)

[4] Badan Pusat Statistik (BPS): Konstruksi Dalam Angka 2017. BPS, Jakarta. pp 1-105 (2017)

[5] Badan Pusat Statistik (BPS): Konstruksi Dalam Angka 2018. BPS, Jakarta. pp 1-103 (2018)

[6] Badan Pusat Statistik (BPS): Konstruksi Dalam Angka 2019. BPS, Jakarta. pp 1-105 (2019)

[7] Hussin, J.M., Rahman I.A., \& Memon A.H.: The Way Forward in Sustainable Construction: Issues and Challenges. Vol 2, pp. 31-42. International Journal of Advances in Applied Sciences. (2013)

[8] Dubois, A. \& Gadde, L. E.: Supply Strategy and Network Effects - Purchasing Behaviour in the Construction Industry. Vol 6, pp. 207-215. European Journal of Purchasing \& Supply Management. (2000)

[9] Agapiou, A., et al.: The role of logistics in the material flow control process. Vol 16, pp. 131-137. Construction Management and Economics. (1998).

[10] Riswandi, et al.: Analisis Faktor-Faktor Yang Mempengaruhi Keuntungan Kontraktor pada Proyek Konstruksi Gedung di Kota Padang 2018. Vol 16, pp. 47-61. JIRS. (2019)

[11] Nunnally, S.W. Construction Methods and Management, 4th ed., Prentice-Hall, Englewood Cliffs, New Jersey. pp. 1-558. (1998)

[12] Tanuwijaya E., \& Sekarsari J.: Analisis Faktor-Faktor Yang Memengaruhi Kontraktor Utama Dalam Pemilihan Subkontraktor Pada Pelaksanaan Proyek Konstruksi. Vol 1, pp. 111-121. Jurnal Mitra Teknik Sipil. (2018)

[13] Benjaoran, V.: A cost control system development: A collaborative approach for small and medium-sized contractors. Vol 27, pp. 270-277. International Journal of Project Management. (2009)

[14] Eom C.S.J., et al.: Subcontractor evaluation and management framework for strategic partnering. Vol 134, pp. 842-851. Journal of Construction Engineering and Management. (2008).

[15] Polat G.: Subcontractor Selection Using The Integration Of The Ahp And Promethee Methods. Vol 22, pp. 1042-1054. Journal of Civil Engineering and Management. (2016)

[16] Ng W. L.: An efficient and simple model for multiple criteria supplier selection problem. Vol 186, pp. 1059-1067. EJ Op Res. (2008)

[17] Bhattacharya A., Geraghty J., \& Young P.: Supplier selection paradigm: an integrated hierarchical QFD methodology under multiple criteria environment. Vol 10, pp. 1013-1027. Appl Soft Comp. (2010)

[18] De Boer L., Labro E., \& Morlacchi P.: A review of methods supporting supplier selection. Vol 7, pp. 75-89. EJ Purch Supply Management. (2001)

[19] Marzouk, M.M., El Kherbawy A.A., and Khalifa M.: Factors influencing sub-contractors selection in construction projects. Vol 9, pp. 150-158. Housing and Building National Research Center. (2013)

[20] Athawale, V. M., Mukherjee, P., \& Chakraborty, S.: Supplier selection using multi-criteria decision-making methods. Vol 8, pp. 41-60. IUP J Op Management. (2009)

[21] Nobar, M., Setak, M., \& Tafti, A.: Selecting suppliers considering features of 2nd layer suppliers by utilizing FANP procedure. Vol 6, pp. 265-275. Int J Bus Management. (2011)

[22] Manoliadis, O., \& Tsolas, I.: Decision analysis framework for vendor selection in construction projects in Greece. Vol 9, pp. 248-261. J Public Procure. (2009)

[23] Kokangul, A., \& Susuz, Z.: Integrated analytical hierarchy process and mathematical programming to supplier selection problem with quantity discount. Vol 33, pp. 1417-1429. Appl Math Modell. (2009)

[24] Mwikali R., \& Kavale S.: Factors Affecting the Selection of Optimal Suppliers in Procurement Management. Vol 2, pp. 189-193. International Journal of Humanities and Social Science. (2012)

[25] De Felice F., et al.: Performance Measurement Model for the Supplier Selection Based on AHP. Vol 7, pp. 1-13. International Journal of Engineering Business Management. (2015)

[26] El-Khalek, H.A., Aziz R. F., and Morgan E.S.: Identification of construction subcontractor prequalification evaluation criteria and their impact on project success. Alexandria Engineering 
Journal. pp. 1-7. (2018)

[27] Ulubeyli S., Manisali E., \& Kazaz A.: Subcontractor selection practices ininternational construction projects. Vol 16, pp. 47 - 56. Journal of Civil Engineering and Management. (2010)

[28] Zulaihah, L. \& Patria R.: Pemilihan Subkontraktor Pt X Dengan Metode Analytical Hierarchy Process. Vol 12, pp. 95-102. Bina Teknika. (2016)

[29] Eriksson, P. E., \& Westerberg, M.: Effects of cooperative procurement procedures on construction project performance: A conceptual framework. Vol 29, pp. 197-208. International Journal of Project Management. (2011)

[30] Hsieh, T. Y.: Impact of subcontracting on site productivity: Lessons learned in Taiwan. Vol 124, pp. 91-100. Journal of Construction Engineering and Management. (1998)

[31] Arditi, D. \& Chotibhongs, R.: Issues in subcontracting practice. Vol. 131, pp. 866-878. Journal of Construction Engineering and Management, (ASCE). (2005)

[32] Choudhry, R. M., et al.: Subcontracting practices in the construction industry of Pakistan. 138, pp. 1353-1359. Journal of Construction Engineering and Management. (2012)

[33] Mbachu, J.: Conceptual framework for the assessment of subcontractors eligibility and performance in the construction industry. Vol 26, pp. 471-484 Construction Management and Economics. (2008)

[34] Garner J.: Cash flow Forecasting: RICS Guidance Note, 1st Edition, Royal Institution of Chartered Surveyors (RICS), UK. Pp. 1-20. (2012)

[35] Cui Q., Hastak M., \& Halpin D.: Systems analysis of project cash flow management strategies. Vol 28, pp. 361-376. Construction Management and Economics. (2010)

[36] Jiang A., Raja R. A. I, \& Maged M.: Construction project cash flow planning using the pareto optimality efficiency network model. Vol 17, pp. 510-519. Journal of Civil Engineering and Management. (2011)

[37] Babalola, A. A. \& Anifowose O.S.: Improving the Profitability of Construction Contracting Firms in Nigeria through Strategic Alliancing Initiatives. Vol 7, pp. 61-67. The International Journal of Engineering and Science. (2018)

[38] Tan, Y., Xue B., \& Cheung Y.T.: Relationships between Main Contractors and Subcontractors and Their Impacts on Main Contractor Competitiveness: An Empirical Study in Hong Kong. Vol 143, pp. 1-11. J. Constr. Eng. Manage. (2017). 